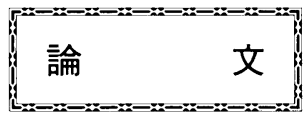

\title{
閃光の実効光度
}

\author{
正会員 古 荘 雅 生 (神户商船大学) 専門会員 河 合 悟 (中京大学)
}

\section{Effective Intensity of a Flash Light}

Member Masao Furusho (Kobe University of Mercantile Marine)

Fellow Member Satoru Kawai (Chukyo University)

\begin{abstract}
We carried out the psychophysical experiment matching and comparing the intensity of a flash light with that of a fixed light, because some papers have reported that the formula for the effective intensity of a flash light presented by Blondel \& Rey in 1912 can not be applied when the background is bright and when the luminance exceeds a certain threshold.

As a result of this experiment, we propose that the effective intensity of a flash light when background condition is 0 $\mathrm{cd} / \mathrm{m}^{2}$ be expressed by

$\log _{\mathrm{e}}(\mathrm{Y})=\left[-4.4+0.88 \times \log _{\mathrm{e}}(\mathrm{X})\right]+0.7 \times \log _{\mathrm{e}}(\mathrm{T})$

$\mathrm{Y}:$ Effective intensity of a flash light in $1 \mathrm{x}$. (Illuminance of a fixed light at the observer's eye in lx.)

$\mathrm{X}$ : Illuminance of a flash light at the observer's eye in $\mathrm{lx}$.

$\mathrm{T}$ : Lighting time period in msec.

KEYWORDS : effective intensity, flash light, fixed light, threshold of luminance, background
\end{abstract}

\section{1. 目的}

海上交通をはじめ，陸上交通，航空交通等の交通システムで用 いられている視覚信号には, 安全を目的としたさまざまな信号が ある。視覚信号のうち短時間に急激な発光で暗の時間より明の時 間の知い閃光は, 誘目性と識別性に優れ, 交通システムには必要 不可久な視覚信号であるといっても過言ではない。

閃光灯火を知覚する心理的な明るさを評価するために，閃光と 同じ明るさに見える定常光の光度でもって表す実効光度という概 念が用いられる。この実効光度としては実験的に求めた Blondel\&Reyの式1に Douglas が修正した次式(1)を用いることが多 w.

$$
\mathrm{Ie}=\frac{\int_{\mathrm{t}_{1}}^{\mathrm{t}_{2}} I d t}{\mathrm{a}+\left(\mathrm{t}_{2}-\mathrm{t}_{1}\right)}
$$

ここで，Ie：実効光度 $(\mathrm{cd}), \mathrm{I}$ ：瞬時光度 $(\mathrm{cd})$

$t_{1}, t_{2}$ : 積分範囲を示す時間 $(\mathrm{sec}), \mathrm{a}$ : 定数 $(0.21)$ である.

しかし，(1)式で得られる実効光度は，実験条件から考之ると夜 間の閾值を与之る実効光度のみであり，同じ夜間であっても閃光 の光度が高光度の場合及び背景の輝度条件が異なる薄明と昼間を 含めた実効光度には適用できないと考えられる．池田らは Xe 白 色閃光の実効光度について, 既にそのことを報告2)している。さら に，その中で背景の輝度を $0,0.1,1,10,100 \mathrm{~cd} / \mathrm{m}^{2}$ の 5 段階 とし, 閃光を閾值, 適正, グレア下限, 上限の 4 条件, さらに閃 光時間を種々に変化させたときの Blondel\&Rey 計算值に対する
相対值を求め, 閾值以外の閃光では極大あるいは極小となる閃光 時間のあることを指摘している。

本研究は, 背景の明るさが $0 \mathrm{~cd} / \mathrm{m}^{2}$ の夜間及び $30 \mathrm{~cd} / \mathrm{m}^{2}$ の薄明 の 2 通りとし, Xe ランプ光源とは異なる白色無電極光源ランプ を用いて, 閃光の明るさを種々の光度として組み合わせ, 閃光の 実効光度 (本論では, 定常光の角膜照度で表し, 以下「実効光度」 とする。）に関する新たな計算式を提案することが目的である.

\section{2. 実験}

\section{1 実験装置}

閃光発生装置を図 1 に，実験装置制御系統を図 2 に示す。光源 には, 松下電工(侏)製の白色(色度 (公表值) : $\mathrm{X}=0.349, \mathrm{Y}=0.360$ ) 無電極点灯ランプ（商品名：エバーライト18）を用いる．光源ラ ンプの主な特徴は, 調光が容易にでき, 立ち上がりが約 $5 \mathrm{msec}$ と いう瞬時点灯が可能であり, 高周波点灯によりフリッカーを生じ ないことである．光源ランプから発せられる光は，発光部に近接 して取り付けられたアパーチャの直径 $3 \mathrm{~mm}$ 中 (視角 2.1 分) の穴を 通過する．閃光及び定常光の明るさは，光源自体の調光割合によ る調整と光学フィルターによる調整との組み合わせにより, フィ ルタ一透過率が $0.02 \sim 100(\%)$ ，観測者の目の位置における角膜 照度で表すと $2.2 \times 10^{-6} \sim 1.1 \times 10^{-2}(\mathrm{~lx})$ までの段階的な変更が可 能である。

両光源の中央には, LED 光源による赤色の光点を十分暗くして 提示し，これを凝視点とする。

被験者の目の位置がずれることにより角膜照度がかわるおそれ 


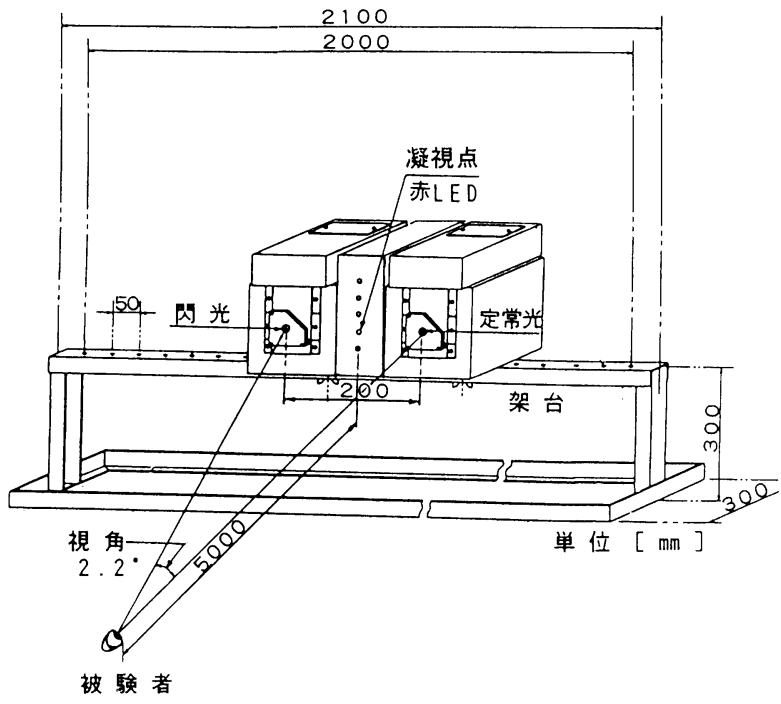

図 1 閃光発生装置

Fig. 1 Flash light indicator

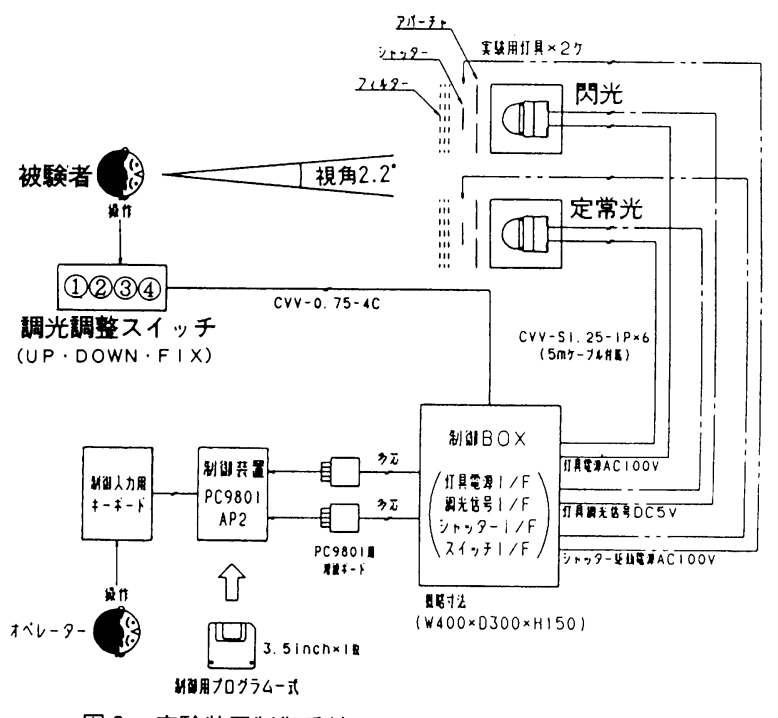

图 2 実験装置制御系統

Fig. 2 Control system of the experimental equipment

をなくすため，あご台を用いる。

閃光及び定常光は，パーソナルコンピュータ及び制御プログラ ムにより閃光の点灯時間, 調光割合, 凝視点とする赤色の LEDの 位置等を変更することができる. 実験は, 標準刺激として閃光を, また比較刺激として定常光を用い, 定常光の制御は, 被験者が調 光割合を $1 \%$ のステップで連続的に操作できるボタン式の調光調 整スイッチを押すことにより調節する。

中心視を考慮し, 閃光と定常光の間隔は $20 \mathrm{~cm}$, 観測距離は $500 \mathrm{~cm}$, 視角は2.2度である。

両光源からの光の強さは, 観測点における法線照度(角膜照度) で表す。

角膜照度を算出するために, 閃光及び定常光について, それぞ れの調光割合に対して測定された輝度計の読みとの関係を図3に 示す。困中の破線は, 近似直線で示される理論的計算値である.

\section{2 実験条件}

実験は, 閃光の点灯時間, 背景の輝度, フィル夕一条件, 被験

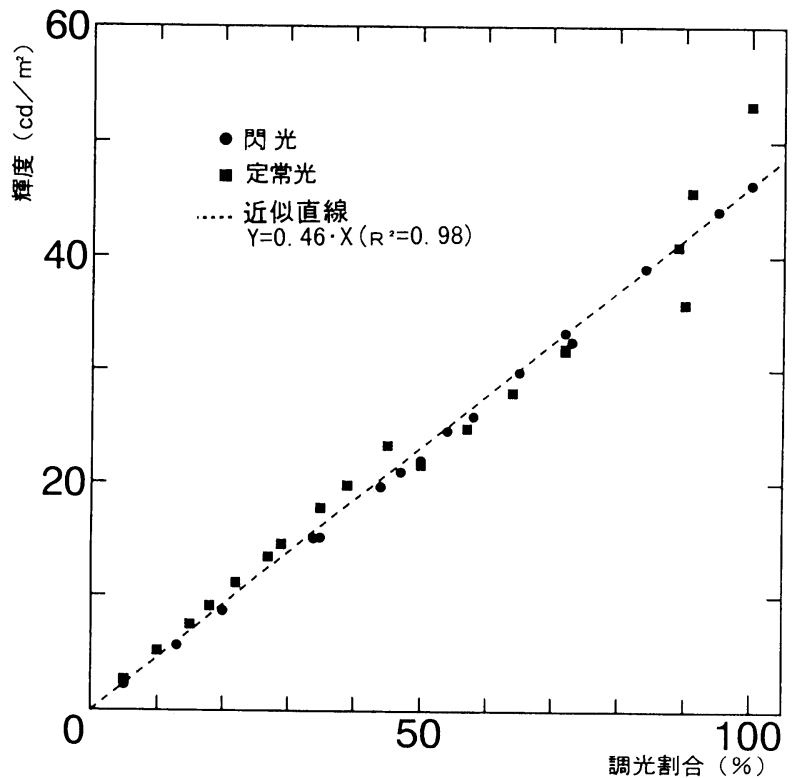

図 3 調光割合と閃光及ひ定常光の輝度

Fig. 3 Luminance of a flash light and fixed light relating to matching ratio

者について，それぞれ次のような実験条件を組み合わせて行う。

閃光の点灯時間は，閃光の立ち上がりと実験装置の特性を考虑 し，上昇系列で $5 \sim 500 \mathrm{msec}$ までとするが，定常光の明るさと閃 光の明るさとが等しいと被験者が判断し，その判断が継続したと ころでその試行を終了する。

閃光の繰り返し間隔は, 被験者が閃光発生ボタンを押し続ける

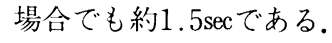

背景の輝度は, 暗室無照明の $0 \mathrm{~cd} / \mathrm{m}^{2}$ 及び监光灯を用いて照明 する $30 \mathrm{~cd} / \mathrm{m}^{2} の 2$ 通りである. 背景とは定常光及び閃光の光源を 中心とする約 2 視野の範囲を示し，凝視点を中心とすると約 4 視野の範囲である。背景輝度の分布については，拡散板を用いた 照明をしていないため完全な均一性はないが, 約 4 視野の範囲を 無作為に抽出して測定した平均値の概略值である。

閃光の光度条件は, 背景の輝度が $0 \mathrm{~cd} / \mathrm{m}^{2}$ の場合, 閃光の角膜 照度で示すと, $2.2 \times 10^{-6}, 8.8 \times 10^{-6}, 2.0 \times 10^{-4}, 5.2 \times 10^{-4}, 1.0 \times$ $10^{-3}, 5.5 \times 10^{-3}, 1.1 \times 10^{-2} \mathrm{l} \mathrm{x}$ の 通りである.また, 背景の輝度 が30cd $/ \mathrm{m}^{2}$ の場合は, $1.0 \times 10^{-4}, 1.0 \times 10^{-3}, 1.1 \times 10^{-2} \mathrm{~lx}$ の 3 通 クである。閃光の光度条件として示す值は, 閃光のピーク值（閃 光の立ち上がりが約 $5 \mathrm{msec}$ ）にフィルター透過率をかけて求め た角膜照度值である。

被験者は, 背景の輝度 $0 \mathrm{~cd} / \mathrm{m}^{2}$ の場合が 3 名, 背景の輝度が 30 $\mathrm{cd} / \mathrm{m}^{2}$ 場合は 2 名で, すべて男性，年㱓は $20 \sim 21$ 才，色覚正常で 視力（含矯正）は0.7〜1.2である.

\section{3 実験方法}

実験は，被験者を実験前約30分間（背景の輝度が $30 \mathrm{~cd} / \mathrm{m}^{2}$ の場 合は約10分間）順応させ, 白色閃光の明るさと等しいと知覚する 白色定常光の明るさを調整しながら決定する調整法という精神物 理学的手法を用いる.

閃光と定常光の被験者への提示は同時に行われ，被験者が定常 光の明るさを決定するまで定常光の提示は継続される．閃光の点 灯時間について，その提示条件はランダムである。そして，一つ の実験条件に対して 3 回の試行を行う. 

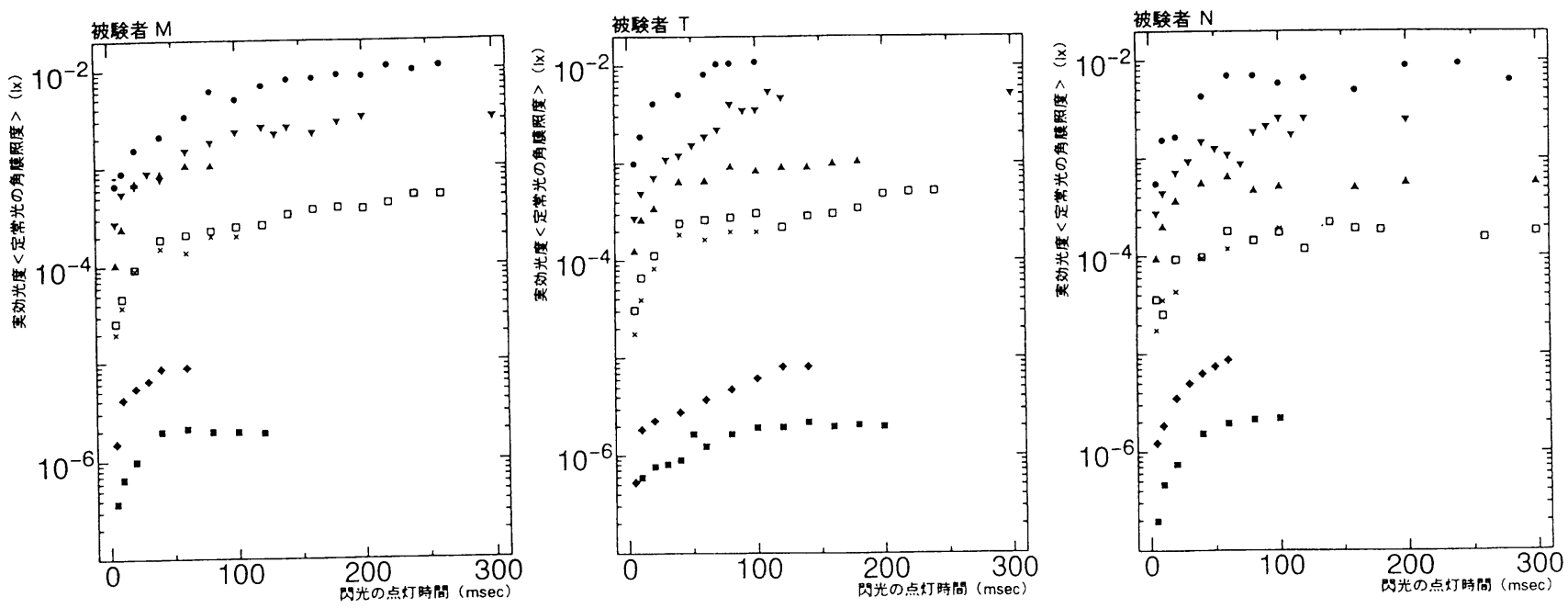

凡例: 閃光の角膜照度 $(1 x)$

- $1.1 \times 10^{-2} \nabla 5.5 \times 10^{-3} \Delta 1.0 \times 10^{-3} \square 5.2 \times 10^{-4} \times 2.0 \times 10^{-4}$

図 4 閃光の点灯時間に対する実効光度

(背景の輝度が $0 \mathrm{~cd} / \mathrm{m}^{2}$ )

Fig. 4 Effective intensity to the duration of a flash light (When background condition is $0 \mathrm{~cd} / \mathrm{m}^{2}$ )
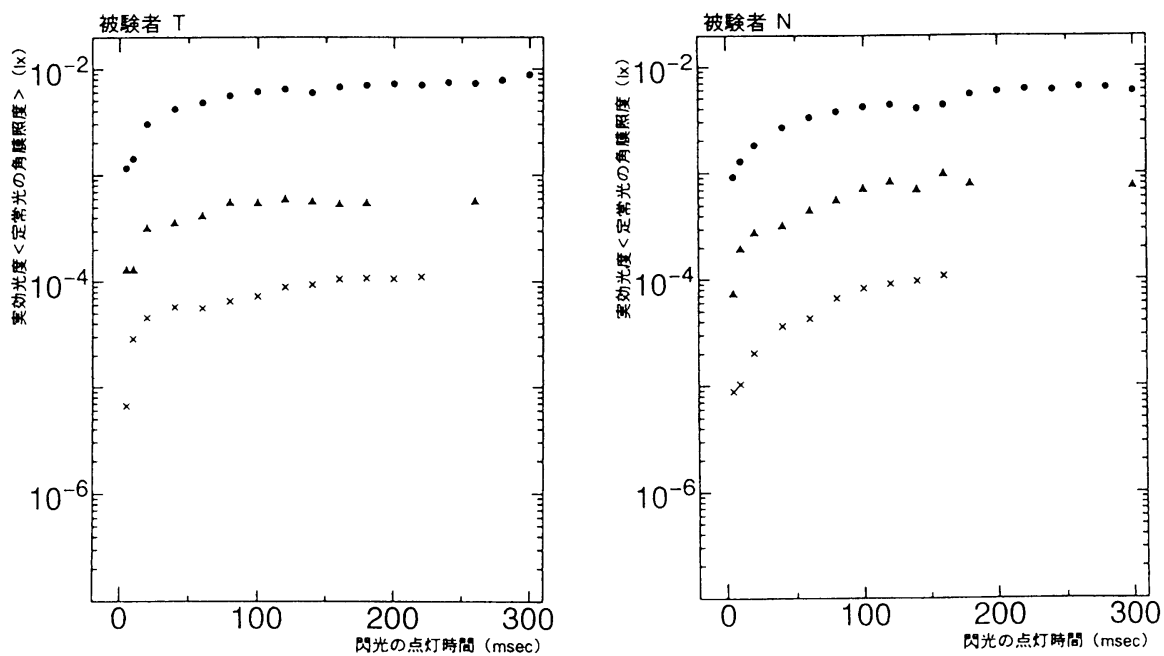

凡例 : 閃光の角膜照度 $(1 \mathrm{x})$

$1.1 \times 10^{-2}$

$\Delta 1.0 \times 10^{-3} \times 1.1 \times 10^{-4}$

\section{図 5 閃光の点灯時間に対する実効光度}

(背景の輝度が $30 \mathrm{~cd} / \mathrm{m}^{2}$ )

Fig. 5 Effective intensity to the duration of a flash light (When background condition is $30 \mathrm{~cd} / \mathrm{m}^{2}$ )

\section{3. 結果}

\section{1 背景の輝度 $0 \mathrm{~cd} / \mathrm{m}^{2}$ の場合}

閃光の点灯時間と定常光の角膜照度で表わす実効光度との関係 を図 4 に示す. 横軸は, 閃光の点灯時間を $\mathrm{msec}$ 単位で目盛り, 縦 軸は実効光度 $(\mathrm{lx})$ の対数で目盛ってある.

実効光度は, 閃光の点灯時間が長くなるにつれて閃光の角膜照 度レベルに達するまで上昇する関係がある。

$30 \mathrm{~mL}$ 以上になると認められるという ${ }^{3)}$ Broca-Sulzer 効果は, 今回の実験では見られなかった。

\section{2 背景の輝度 $30 \mathrm{~cd} / \mathrm{m}^{2}$ の場合}

閃光の点灯時間と実効光度との関係を図 5 に示す.

閃光の点灯時間に対する実効光度は, 被験者の違い, あるいは, 閃光の角膜照度レベルの違いにかかわらず，閃光の点灯時間がお よそ40msec までの範囲で急上昇し，その後緩やかに上昇しなが ら閃光の角膜照度レベルまで達するという傾向を示している.

\section{4. 検討及び考察}

\subsection{Blondel-Rey の式から求められる実効光度}

Blondel-Reyによる(1)式は，閃光の点灯時間がおよそ500msec までの短い時間範囲では当てはまらないことが既に発表されてい $3^{2(4) 5)}$.

今回の実験結果においても，(1)式に当てはまらないことは図 6 に示すとおりである．产線で示す Blondel-Rey 值は，常に実測值 （各被験者データの平均值）以下である。

そこで, 閃光の実効光度を推定するために，実験デー夕に当て はめた近似関数から実験式を求めるというアプローチを行う。 


\section{2 実効光度を求めるための実験式}

実験デー夕の定性的な傾向を調べるため，デー夕解析ソフト

「Ngraph Ver.5.31」6)を用いて最小二乗法により関数を求める. まず, 各被験者のデー夕に相関係数が 0.9 以上で最もよくフィッ 卜する関数を求めると, 次式(2)で近似される「べき関数」を得る.

$\log _{\mathrm{e}}(\mathrm{Y})=\beta_{\mathrm{N}}+\alpha_{\mathrm{N}} \times \log _{\mathrm{e}}(\mathrm{T})$

ここで，T は閃光の点灯時間 $(\mathrm{msec}), \mathrm{Y}$ は実効光度 $(\mathrm{lx}), \alpha_{\mathrm{N}}$, $\beta_{\mathrm{N}}$ は係数である.

これは, 実効光度の対数が, 閃光の点灯時間の対数と高い相関 があり，閃光の角膜照度レベルに達することを意味する。

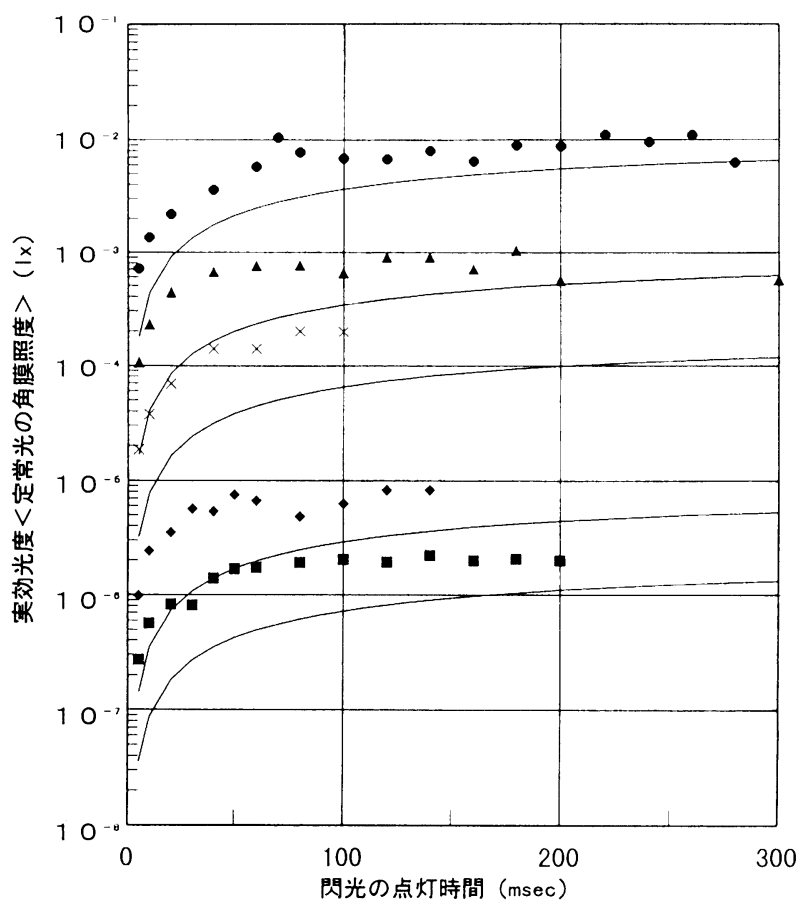

凡例：閃光の角膜照度 $(1 \mathrm{x})$

$$
\begin{aligned}
& -1.1 \times 10^{-2} \quad \Delta 1.0 \times 10^{-3} \times 2.0 \times 10^{-4} \\
& \bullet 8.8 \times 10^{-0} \quad 2.2 \times 10^{-0}-\text { Blondel-Rey值 }
\end{aligned}
$$

图 6 閃光の点灯時間に対する実効光度及ひ Blondel-Rey 值

Fig. 6 Effective intensity to the duration of a flash light and Blondel-Rey value
係数 $\alpha_{\mathrm{N}}$ は, 閃光の点灯時間の対数に対する実効光度の増加率を 表す．また，係数 $\beta_{\mathrm{N}}$ は，閃光の角膜照度レベルをパラメータとす る実効光度の $\mathrm{Y}$ 切片を表すと考えることができる.

近似式の係数 $\alpha_{\mathrm{N}}, \beta_{\mathrm{N}}$, ポイントデー夕数及び相関係数について, 背景の輝度が $0 \mathrm{~cd} / \mathrm{m}^{2}$ の場合を $\alpha_{\mathrm{N}}=\alpha 1, \beta_{\mathrm{N}}=\beta 1$, 背景の輝度 が $30 \mathrm{~cd} / \mathrm{m}^{2}$ の場合を $\alpha_{\mathrm{N}}=\alpha 2, \beta_{\mathrm{N}}=\beta 2$ として, 表 1 及び表 $2 に$ 示す.

\section{2 .1 背景の輝度 $0 \mathrm{~cd} / \mathrm{m}^{2}$ の場合}

表 1 の係数 $\alpha_{1}$ は, 閃光の角膜照度レベルや被験者の違いによる

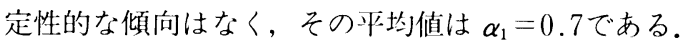

表 1 の係数 $\beta_{1}$ と閃光の角膜照度との関係を図 7 に示す. 係数 $\beta_{1}$ は閃光の角膜照度の対数に比例し，図中の破線が表す次式(3)で近 似される。

$\beta_{1}=-4.4+0.88 \times \log _{\mathrm{e}}(\mathrm{X})$

ここで, X は閃光の角膜照度 $(\mathrm{lx})$ である.

(2)式に $\alpha_{1}$ 及び(3)式の $\beta_{1}$ を代入すると，実効光度は次式(4)とな る.

$\log _{\mathrm{e}}(\mathrm{Y})=\left[-4.4+0.88 \times \log _{\mathrm{e}}(\mathrm{X})\right]+0.7 \times \log _{\mathrm{e}}(\mathrm{T})$

ここで, $\mathrm{Y}$ は実効光度 $(\mathrm{lx}), \mathrm{X}$ は閃光の角膜照度 $(\mathrm{lx}), \mathrm{T}$ は閃 光の点灯時間 $(\mathrm{msec})$ である.

表 2 近似式の係数 $\alpha_{2}$, 係数 $\beta_{2}$, ポイントデータ数及び相関係数(背景の輝度 $30 \mathrm{~cd} / \mathrm{m}^{2}$ の場合)

Table 2 Coefficient $\alpha_{1}, \beta_{1}$ of the approxmate formula, number of data and

\begin{tabular}{|c|c|c|c|c|}
\hline \multicolumn{2}{|c|}{ 閃光の角膜照度 (1x) } & \multirow{2}{*}{ 1. $1 \times 10^{-4}$} & \multirow{2}{*}{$1.0 \times 10^{-3}$} & \multirow{2}{*}{$1.1 \times 10^{-2}$} \\
\hline 保 数 & 被铁者 & & & \\
\hline \multirow{2}{*}{$\alpha_{2}$} & $\mathrm{~T}$ & 0.60 & 0.52 & 0.47 \\
\hline & $N$ & 0.78 & 0.64 & 0.48 \\
\hline \multirow{2}{*}{$\beta_{2}$} & $\mathrm{~T}$ & -12.22 & -9.88 & -7.38 \\
\hline & $\mathrm{N}$ & -12.16 & -10.40 & -8.26 \\
\hline \multirow{2}{*}{$\begin{array}{c}\text { ホイイント } \\
\text { デ-タ } \\
\text { 数 }\end{array}$} & $\mathrm{T}$ & 13 & 8 & 17 \\
\hline & N & 10 & 11 & 17 \\
\hline \multirow{2}{*}{$\begin{array}{l}\text { 相 } \\
\text { 倸数 }\end{array}$} & $\mathrm{T}$ & 0.94 & 0.97 & 0.98 \\
\hline & $N$ & 0.99 & 0.98 & 0.99 \\
\hline
\end{tabular}
coefficient of correlation (When background condition is $30 \mathrm{~cd} / \mathrm{m}^{2}$ )

表 1 近似式の係数 $\alpha_{1}$, 係数 $\beta_{1}$, ポイントデータ数及び相関係数 (背景の輝度 $0 \mathrm{~cd} / \mathrm{m}^{2}$ の場合）

Table 1 Coefficient $\alpha_{1}, \beta_{1}$ of the approxmate formula,number of data and

\begin{tabular}{|c|c|c|c|c|c|c|c|c|}
\hline \multicolumn{2}{|c|}{ 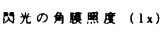 } & \multirow{2}{*}{$2.2 \times 10^{-6}$} & \multirow{2}{*}{$8.8 \times 10^{-6}$} & \multirow{2}{*}{$2.0 \times 10^{-4}$} & \multirow{2}{*}{$5.2 \times 10^{-4}$} & \multirow{2}{*}{$1.0 \times 10^{-3}$} & \multirow{2}{*}{$5.5 \times 10^{-3}$} & \multirow{2}{*}{$1.1 \times 10^{-2}$} \\
\hline ( & 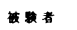 & & & & & & & \\
\hline \multirow{3}{*}{$\alpha$} & M & 0.53 & 0.68 & 0.77 & 0.72 & 0.84 & 0.63 & 0.76 \\
\hline & $\mathrm{T}$ & 0.47 & 0.72 & 0.82 & 0.63 & 0.56 & 0.84 & 0.82 \\
\hline & $\mathrm{N}$ & 0.81 & 0.81 & 0.77 & 0.65 & 0.78 & 0.63 & 0.69 \\
\hline \multirow{3}{*}{$\beta}$, & M & -15.47 & -14.25 & -11.91 & -11.54 & -10.03 & -9.15 & -8.72 \\
\hline & $T$ & -15.45 & -15.29 & -12.04 & -11.09 & -9.66 & -9.59 & -8.16 \\
\hline & $\mathrm{N}$ & -16.57 & -14.98 & -12.16 & -11.52 & -10.40 & -9.15 & -8.26 \\
\hline \multirow{3}{*}{ 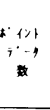 } & M & 8 & 6 & 7 & 15 & 6 & 15 & 15 \\
\hline & $\mathrm{T}$ & 13 & 9 & 7 & 14 & 11 & 14 & 8 \\
\hline & $\mathrm{N}$ & 7 & 7 & 6 & 6 & 5 & 14 & 10 \\
\hline \multirow{3}{*}{ 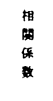 } & M & 0.95 & 0.96 & 0.98 & 0.99 & 0.96 & 0.98 & 0.99 \\
\hline & $\mathrm{T}$ & 0.95 & 0.97 & 0.97 & 0.96 & 0.98 & 0.97 & 0.99 \\
\hline & $\mathrm{N}$ & 0.99 & 0.99 & 0.99 & 0.91 & 0.99 & 0.94 & 0.94 \\
\hline
\end{tabular}
coefficient of correlation (When background condition is $0 \mathrm{~cd} / \mathrm{m}^{2}$ ) 


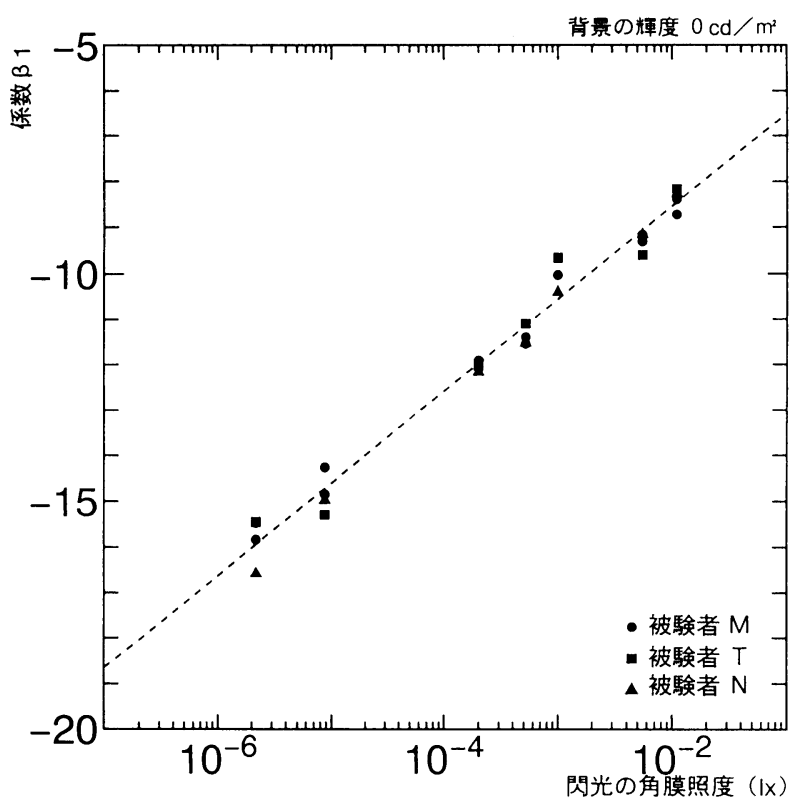

図 7 係数 $\beta_{1}$ と閃光の角膜照度との関係

Fig. 7 Relation between coefficient $\beta_{1}$ and illuminance of a flash light at the obserber's eye

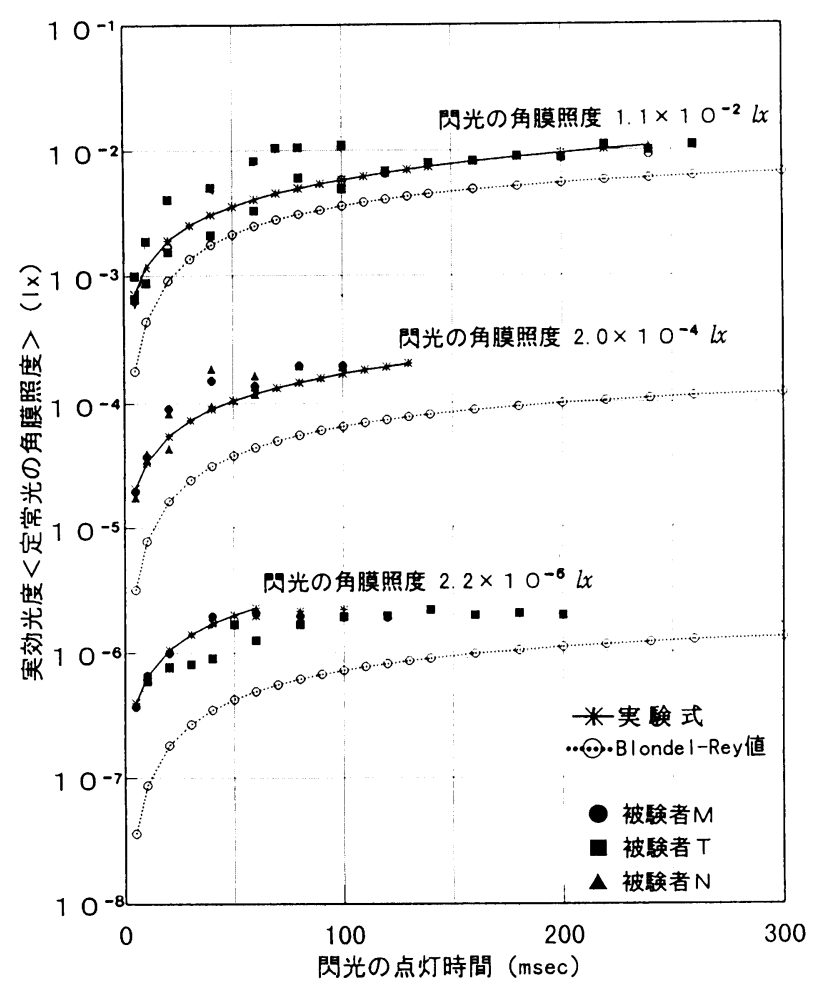

\section{图 8 閃光の点灯時間に対する実効光度}

(背景の輝度が $0 \mathrm{~cd} / \mathrm{m}^{2}$ )

Fig. 8 Effective intensity to the duration of a flash light (When background condition is $0 \mathrm{~cd} / \mathrm{m}^{2}$ )

背景の輝度が $0 \mathrm{~cd} / \mathrm{m}^{2}$ の場合, 閃光の角膜照度が $2.2 \times 10^{-6}$, $2.0 \times 10^{-4}, 1.1 \times 10^{-2} \mathrm{~lx}$ の 3 レベルについて, (4)式で与える実験式 及び(1)式を用いた Blondel-Rey 值も含めて実験結果に重ねたも のを図8に示す。

\section{2 .2 背景の輝度 $30 \mathrm{~cd} / \mathrm{m}^{2}$ の場合}

表 2 の係数 $\alpha_{2}$ 及び $\beta_{2}$ の閃光の角膜照度に対する関係を図 9 に 示す．被験者両名ともに閃光の角膜照度が大きくなるにつれて,

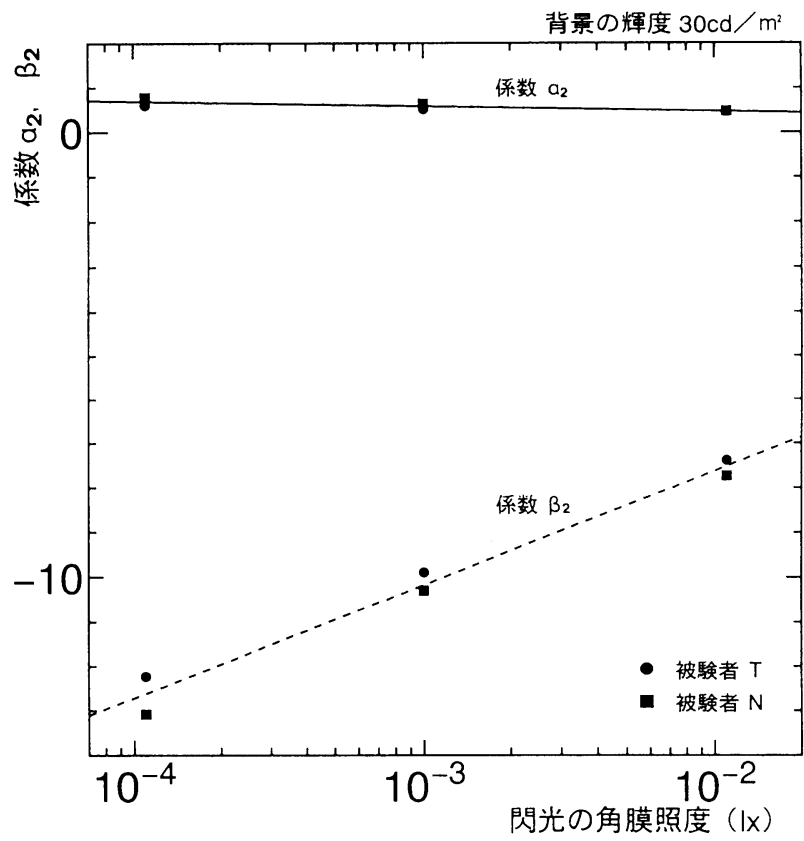

図 9 係数 $\alpha_{2}$, 係数 $\beta_{2}$ と閃光の角膜照度との関係

Fig. 9 Relation between coefficient $\alpha_{2}, \beta_{2}$ and illuminance of a flash light at the obserber's eye

係数 $\alpha_{2}$ は小さくなる傾向があり, 図中の実線が表す次式(5)で近似 される.

$\alpha_{2}=0.25-0.05 \times \log _{e}(X)$

ここで，Xは閃光の角膜照度 $(1 \mathrm{x})$ である.

また，係数 $\beta_{2}$ は閃光の角膜照度の対数と高い相関があり, 四中 の破線が表す次式(6)で近似される.

$\beta_{2}=-2.5+1.1 \times \log _{\mathrm{e}}(\mathrm{X})$

ここで，Xは閃光の角膜照度 $(1 \mathrm{x})$ である.

(2)式に(5)式で示される $\alpha_{2}$ 及び(6)式で示される $\beta_{2}$ を代入すると， 実効光度は次式(7)となる。

$$
\begin{aligned}
\log _{\mathrm{e}}(\mathrm{Y}) & =\left[-2.5+1.1 \times \log _{\mathrm{e}}(\mathrm{X})\right]+\left[0.25 \cdots 0.05 \times \log _{\mathrm{e}}(\mathrm{X})\right] \\
& \times \log _{\mathrm{e}}(\mathrm{T}) \quad \cdots \cdots \cdots \cdots \cdots \cdots \cdots \cdots \cdots \cdots \cdots \cdots \cdots \cdots \cdots \cdots \cdots \cdots \cdots \cdots \cdots \cdots \cdots \cdots \cdots \cdots \cdots \cdots \cdots
\end{aligned}
$$

ここで, $\mathrm{Y}$ は実効光度 $(\mathrm{x}), \mathrm{X}$ は閃光の角膜照度 $(\mathrm{x}), \mathrm{T}$ は 閃光の点灯時間 $(\mathrm{msec})$ である.

背景の輝度が $30 \mathrm{~cd} / \mathrm{m}^{2}$ の場合, 閃光の角膜照度が $1.1 \times 10^{-4}$, $1.0 \times 10^{-3}, 1.1 \times 10^{-2} \mathrm{l} \times$ の 3 レベルについて, (7)式で与える実験式 を実験結果に重ねたものを図10に示す。

今回の実験では背景の輝度が $30 \mathrm{~cd} / \mathrm{m}^{2}$ の場合のみを行ったが, 他の背景の輝度条件についても, さらなる実験の追加が必要であ ると考える。

今回の実験により考察できることは，背景が多少なりとも明る い場合には，背景が $0 \mathrm{~cd} / \mathrm{m}^{2}$ の場合と比べて，閃光の見え方は異 なっているといえる. 背景輝度と䦨值を与える実効光度との関係 について, Blondel\&Reyの式で計算できるのは背景輝度 $1 \mathrm{~cd} / \mathrm{m}^{2}$ 以下の夜間の閾值を与える実効光度のみであるとする報告7もあ り, 薄明及び昼間を通じて使用できる実効光度を与える式が検討 されなければならないと考える。

\section{3 実験式の検討（背景の輝度 $0 \mathrm{~cd} / \mathrm{m}^{2}$ の場合）}

本実験に先立ち，スライドプロジェクターに回転スリット及び 電子シャッターを取り付けた閃光発生装置を作製し, 閃光の点灯 時間が $1 \mathrm{msec}$ 付近で, 背景の輝度が $0 \mathrm{~cd} / \mathrm{m}^{2}$ の場合の実験を行 っている. 被験者は, 本実験と同じ 3 名である. 被験者は定常光 


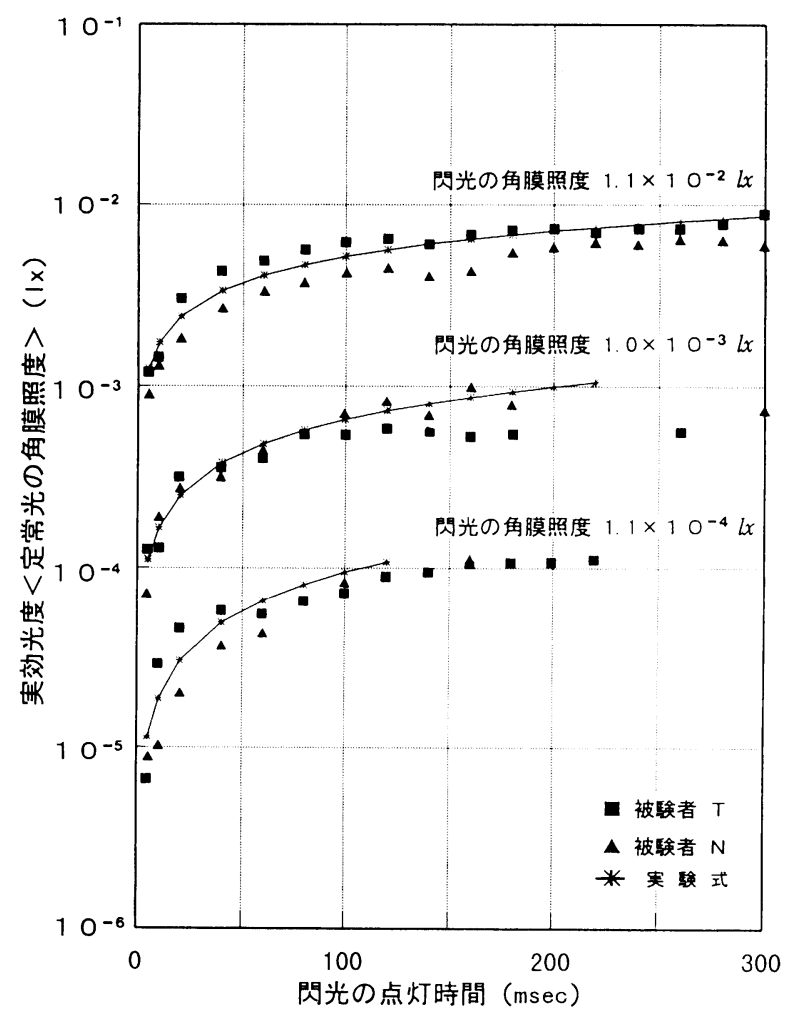

图10 閃光の点灯時間に対する実効光度 (背景の輝度が $30 \mathrm{~cd} / \mathrm{m}^{2}$ )

Fig.10 Effective intensity to the duration of a flash light (When background condition is $30 \mathrm{~cd} / \mathrm{m}^{2}$ )

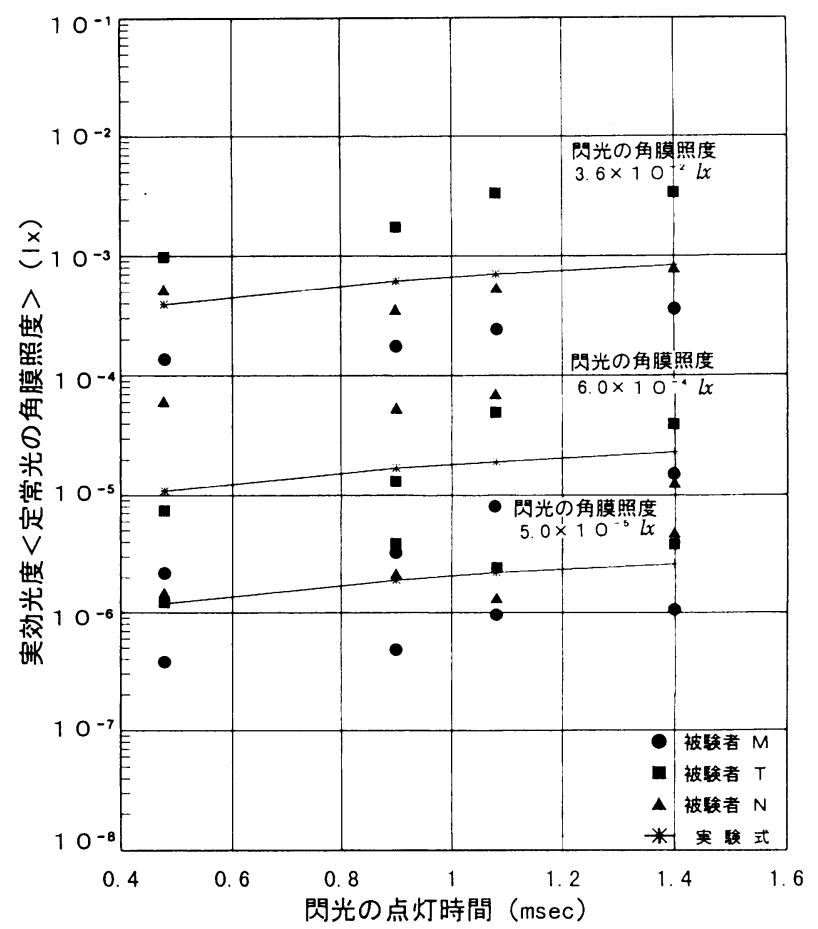

图11 閃光の点灯時間に対する実効光度

(背景の輝度 $0 \mathrm{~cd} / \mathrm{m}^{2}$, 閃光の点灯時間 $1 \mathrm{msec}$ 近傍の場合)

Fig.11 Effective intensity to the duration of a flash light

(When background condition is $0 \mathrm{~cd} / \mathrm{m}^{2}$ and when the duration of a flash light is about $1 \mathrm{msec}$ )
の電源電圧を変えながら閃光と同じ明るさに見える定常光の明る さを決定する，そして，電源電圧と閃光及び定常光の輝度を测定 し，角膜照度に換算したものである。そのようにして求めた結果 に実験式(4)を当てはめたものを, 閃光の角膜照度レベルに対応さ せ図11に示寸。閃光の点灯時間は，回転スリットの回転数から求 めた值である。

その結果，被験者の個人差は大きいものの，それぞれの被験者 の平均的な傾向が示すように，実験式(4)に当てはまることが確認 される。

\section{5.結言}

閃光の実効光度 (角膜照度) を求めるために, 閃光の明るさと 背景の輝度の諸条件を組み合わせ，被験者が閃光の明るさと等し いと感じられる定常光の明るさを閃光の実効光度とするような実 験に基づく本研究をまとめると，次のようになる。

(1) 閃光の実効光度は, 背景の輝度が一定の条件であるとき，閃 光の角膜照度 $(\mathrm{lx})$ と閃光の点灯時間 $(\mathrm{msec})$ をパラメータとし て，求めることができる.

(2) 背景の輝度が $0 \mathrm{~cd} / \mathrm{m}^{2}$ の場合, 閃光の実効光度は次の実験式 で与えられる。

$\log _{\mathrm{e}}(\mathrm{Y})=\left[-4.4+0.88 \times \log _{\mathrm{e}}(\mathrm{X})\right]+0.7 \times \log _{\mathrm{e}}(\mathrm{T})$

$\mathrm{Y}$ : 実効光度（定常光の角膜照度）（1x）

$\mathrm{X}$ ：閃光の角膜照度 $(1 \mathrm{x})$

$\mathrm{T}$ ：閃光の点灯時間 $(\mathrm{msec})$

（3）背景の輝度が $0 \mathrm{~cd} / \mathrm{m}^{2}$ 以外の場合，すなわち背景に明るさが ある場合の閃光の実効光度は，背景が $0 \mathrm{~cd} / \mathrm{m}^{2}$ の場合とは異なっ た值となる。

\section{参 考 文 献}

(1) Blondel and Rey "Perception of Lights of short duration at their range limits." Transaction of Illuminating Engineering London, Vol VII No.8 P.625 662 (1912)

（2）池田紘一, 藤井克人, 小原清成：「Xe 白色閃光の実効光 度」, 昭60照学全大，63，(1985)

(3) 大山正 - 今井省吾 - 和気典二編, 新編感覚 - 知覚心理学八 ンドブック，誠信書房，p.337，(1994）

（4）池田紘一・藤井克人 - 中山昌春 - 小原清成：「閃光灯火の 色と実効光度」，昭61照学全大，62，(1986)

（5）小野 隆, 大野義明, 小木曾淳一, 石井弘允：「パルス発 光光源の実効光度の検討 ( I ) 」, 平 4 照学全大, 88 , (1992)

（6）ネットワーカーマガジン編集部／月刊アスキー編集部，秀 作フリーソフトウェア100選 Part 2, 侏アスキー（ISBN47561-0541-6), (1994)

(7) (社)照明学会航空障害標識に関する調査特別研究委員会, 航 空障害灯及び障害標識に関する調査（II）報告書，p.27， (1993)

（受付日1996年 7 月 19 日／採録日1997年 2 月 3 日） 